\title{
Effects of trap design, independence of traps and bait on sampling populations of spanner crabs Ranina ranina
}

\author{
Steven J. Kennelly, James R. Craig \\ NSW Agriculture \& Fisheries, Fisheries Research Institute, PO Box 21, Cronulla, NSW 2230, Australia
}

\begin{abstract}
Techniques were developed in several field experiments which quantify relative abundances and size-structures of populations of spanner crabs Ranina ranina (Linnaeus) using catch per unit of effort data (CPUE) from baited trapping. Effects on CPUE due to 2 shapes of traps, 3 mesh-sizes and 2 strand-thicknesses of nets, and 2 methods of hanging nets were investigated in a fully-orthogonal manipulative experiment. Replicates of these treatments were randomly located in each of 3 depth ranges in the $R$. ranina fishing grounds off the east coast of NSW, Australia. The time required and damage incurred by crabs during removal from various types of traps were quantified. Independence of data from replicate traps was investigated by comparing CPUE from traps set in close proximity with traps set individually. Effects of bait on CPUE were investigated by using different kinds of bait on replicate traps. Results showed that traps with $85 \mathrm{~mm}, 4$-ply net hung doubly caught significantly more R. ranina than all other combinations of mesh, ply and methods of hanging nets. This trap also caught proportionately more crabs of commercial value than other traps. The presence of a metallic border around traps did not have any significant effect on CPUE. Small-meshed traps caused more dactyli to be removed from crabs during disentanglement, but more whole limbs were removed from crabs caught on larger meshes. Larger meshes also required significantly more time to clear crabs. Traps set $60 \mathrm{~m}$ apart caught as many crabs as traps set much further apart - indicating true independence between replicates. Bait-type had no significant effect on CPUE. Middle-depths in the fishing grounds had significantly more $R$. ranina available for capture than shallower and deeper grounds at this time of sampling. We derived an optimal sampling strategy to be used in subsequent sampling of distributions and abundances of $R$ ranina and stress the worth of field experimentation in testing specific hypotheses about this species' ecology and fishery.
\end{abstract}

\section{INTRODUCTION}

The efficiency of gear in catching target species is of inherent concern to commercial fishing, fisheries research and resource management (Jester 1977. Sissenwine \& Kirkley 1982). Fisheries research involving the sampling of populations of animals usually employs catch per unit of effort data (CPUE) to estimate relative abundances and age/size structures of exploited populations. This requires accurate estimates of both catch and effort (Collie \& Sissenwine 1983; for review see Sissenwine 1984). Although data on catch are relatively simple to obtain as counts and measurements of caught animals, the effort involved in obtaining given catches is more difficult to quantify and standardize. Ideally, methods should be uniform, unbiased, optimal with respect to the quantity of catch obtained, and replicated in space and time so as to allow reliable estimates of relative abundances and size-structures of target species. Experiments to assess methods that sample abundances of commerciallyimportant marine species have been conducted in many fisheries (Larkins 1963, 1964, Jester 1973, Hamley 1975, Kjelson \& Colby 1977, Fogarty \& Bordin 1980; see review by Sissenwine et al. 1983).

Several papers have dealt with methods that sample exploited populations of large decapods using CPUE data from baited trapping (Thomas 1953, Sinoda \& Kobayasi 1969, Miller 1978, 1979, 1981, 1983). These papers point out several factors that may influence catches, apart from the absolute abundances of crabs and lobsters, including the shape of traps, the net used in traps, the bait used, competition between traps, the soak-time of traps (length of time traps are available to animals), and the position of fishing effort in space and time. In this paper we consider the first 4 of these 


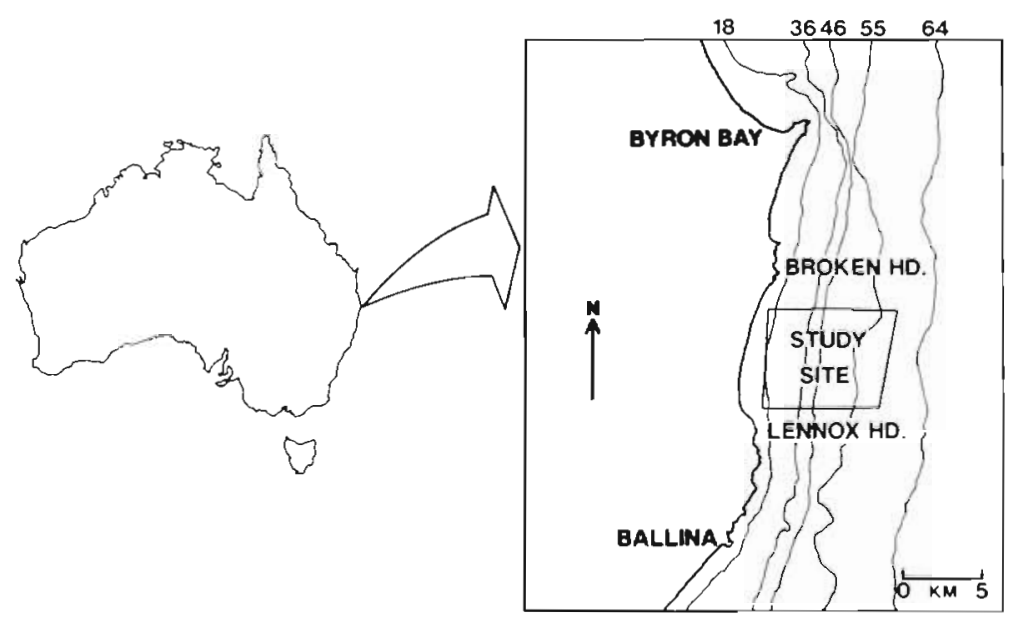

Fig. 1. Location of study site. Depth contours in metres

factors in determining a strategy to be used in subsequent sampling of the relative abundances of commercially-important populations of the spanner crab Ranina ranina (Linnaeus) off the east coast of Australia. Influences on the developed sampling tool due to different soak-times and inherent spatial and temporal variability in $R$. ranina's distributions are covered elsewhere (Kennelly unpubl).

Ranina ranina are large marine brachyurans found throughout the Indo-Pacific region (Barnard 1950). They are found in coastal waters in depths of 10 to $80 \mathrm{~m}$ on sandy substrata in which they burrow (Skinner \& Hill 1987). Populations of $R$. ranina have been exploited commercially in Hawaii, Japan, the Philippines and recently, the east coast of Australia (Skinner \& Hill 1986). There have been, however, only a few studies concerning the biology and ecology of this valuable species (Onizuka 1972, Fielding \& Haley 1976, Tahil 1983, Brown 1986, Skinner \& Hill 1986, 1987) and so several basic aspects of its biology are unknown. Of particular relevance to resource management are the distributions, abundances and growth rates of the species.

Studying these aspects of the biology of Ranina ranina requires a long-term survey of abundances across a variety of spatial and temporal scales using standard and accurate methods. SCUBA counting and remote sensing techniques are not useful as $R$. ranina is buried for most of the time (Skinner \& Hill 1986) and so invisible to passive observation. The best way to quantify the abundances of these organisms is therefore to catch them using a standard sampling procedure to provide CPUE data. Fishing techniques using tangle traps have been developed to catch commercial quantities of $R$. ranina but these are specifically aimed at legal-sized crabs (>93 mm carapace length in New South Wales). To determine the best technique for sampling entire populations of $R$. ranina, it was necessary to conduct several pilot experiments to test effects on the CPUE of crabs due to different shapes of traps, mesh sizes, strand thicknesses, methods of hanging nets, and competition among individual traps (i.e. the independence of replicates). Further, because tangle-trap methods of capture necessitate disentanglement of crabs, we considered the time taken to remove crabs from different types of gear, and the damage incurred to crabs during removal (and prior to return to the sea in the case of undersize crabs).

\section{MATERIALS AND METHODS}

This study was conducted on sandy substrata offshore from Lennox Head, NSW, Australia $\left(28^{\circ} 47^{\prime} \mathrm{S}\right.$, $153^{\circ} 39^{\prime} \mathrm{E}$ ); the same fishing grounds as those used by commercial fishermen (Fig. 1). To obtain CPUE data, we used modifications of commercial fishing methods. Crab traps were flat frames enclosing an area of $1.2 \times$ $1.2 \mathrm{~m}$ and made of mild steel. Different kinds of netting were suspended over each frame allowing a standard $230 \mathrm{~mm}$ drop. One piece of bait (fish-head and skeleton) was placed on a metal bar in the middle of each frame. Preliminary observations with commercial fishermen revealed that the quantity of bait had no effect on CPUE. Several traps were set out together along a trot-line that was placed on the substratum cross-current in the area and depth-range to be sampled. Such sets of traps were left for a given soak-time during which individual Ranina ranina were attracted to the bait from down-current and became entangled on the net before reaching the bait (evidenced by the locations of crabs on traps). When traps were hauled, crabs were disentangled, counted, measured (anterior [eye-orbit] to posterior carapace length), sexed and then thrown back.

Expt 1a - Effects on CPUE due to depth, shapes of traps, mesh-sizes of nets, strand-thicknesses of nets and methods of hanging nets. Twenty-four different 
kinds of traps were used in a stratified, fully orthogonal design. The nets used on individual traps were of all possible combinations of: 3 different mesh-sizes $(25 \mathrm{~mm}, 85 \mathrm{~mm}, 150 \mathrm{~mm}) ; 2$ different strand thicknesses (thin - 4- to 6-ply and thick - 12-ply); and 2 ways of hanging the nets (a single layer and 2 layers of net). All these combinations were hung on both square frames (with a metallic border) and X-shaped frames (with a thin, nylon border) to isolate any effects on CPUE of metallic borders.

These 24 different traps were arranged into 3 sets of 8 traps. The 8 traps on each set were spaced $60 \mathrm{~m}$ apart. Each set contained all traps of a given mesh-size arranged randomly. Each set was left on the substratum for a soak-time of ca 90 min before collection, sampling, rebaiting, re-randomizing the order of traps along a set, and re-setting the gear in a new location. Over a period of $4 \mathrm{~d}$ in July 1987, each of these sets of traps was set 5 times at random in 3 depth ranges: shallow (16 to $24 \mathrm{~m}$ ), mid-depth (32 to $40 \mathrm{~m}$ ) and deep ( 54 to $60 \mathrm{~m}$ ). Because the 24 traps had to be arranged in groups of similar mesh sizes, catch rates may be correlated across the 8 different traps on a set and within mesh sizes. This can affect the analyses of variance, causing some tests to be too liberal and others too conservative. This possibility was investigated by a Tukey's test of non-additivity (Scheffé 1959) - see below.

Expt $1 b-$ Effects of different types of gear on clearing time and damage to crabs. Two replicates of each of the 24 different traps were sampled for the time taken to disentangle crabs from traps by one operator. This was recorded as the average time taken per crab, per trap-lift. Two replicates of each of the 24 different traps were also sampled for the amount of damage incurred to each crab upon removal. This was recorded as the number of dactyli and/or whole limbs removed per crab, per trap-lift.

Expt 2 - Effects on CPUE due to competition among traps for crabs and types of bait. To determine if CPUE is affected by competition among neighbouring traps joined together in a single set, we laid out 2 sets containing 6 traps each placed $60 \mathrm{~m}$ apart and compared these to 12 individual traps spaced by more than $120 \mathrm{~m}$. Commercial fishermen claim that at $60 \mathrm{~m}$ apart, traps do not compete, and this was confirmed by us in a pilot experiment using traps set at 10,50 and $100 \mathrm{~m}$ apart (unpubl.). The traps used in this experiment were square-framed with $85 \mathrm{~mm}, 4$ - to 6-ply net doubly hung - the optimal kind of trap determined in Expt 1 (see 'Results'). All gear was set for a soak-time of 90 min in each of 2 random locations (Places 1 and 2), retrieved, sampled and then the whole procedure repeated.

Incorporated in this experimental design was a test for differences in CPUE due to different baits which

\section{Ranina ranina SIZE FREQUENCIES}

- LENNOX HEAD : JULY, 1987

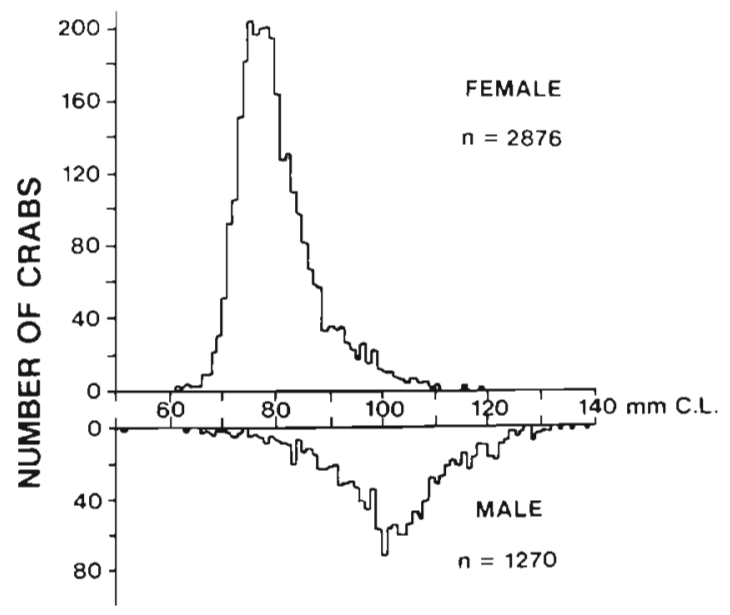

Fig. 2. Ranina ranina. Size-structure of the population of males and females at the study site

would be available in future sampling. Within each group of 6 traps (whether in a set or individually), 2 were baited with mullet Mugil cephalus (Linnaeus), 2 with blackfish Girella tricuspidata (Quoy \& Gaimard) and 2 with morwong Cheilodactylus douglassil (Hector).

Analyses of data. The measurements of all Ranina ranina obtained in Expt 1a were combined to determine the overall size distribution of the population studied. Females were generally smaller and more abundant than males (Fig. 2), and so size-classes for subsequent analyses of data were different for each sex. From the data from each replicate trap in Expts 1 a and 2 , we derived the percentage of crabs caught in each of the following size-classes: males: $\leqslant 79,80-89$, $90-99, \quad 100-109,110-119$ and $\geqslant 120 \mathrm{~mm}$; females: $\leqslant 69,70-79,80-89,90-99,100-109$ and $\geqslant 110 \mathrm{~mm}$. Further, and of particular interest to commercial fishermen, the percentage of crabs that were male and $\geqslant 93 \mathrm{~mm}$ were determined for each trap (those crabs that are usually retained for sale). We also determined the total number of crabs caught on each trap.

The data from each experiment were firstly tested for homogeneity of variances (Cochran's test), then analysed in the relevant 5-factor analysis of variance (Expt 1a) or 4-factor analysis of variance (Expts 1 b and 2); means were then compared using Ryan's tests (Ryan 1959). Those sets of data with homogeneous variances that showed significant effects in the analyses of variance and subsequent Ryan's tests are presented below. These data were also analysed using a 4 -factor version of Tukey's test for non-additivity to test the significance of interactions between set and trapshape, ply and hanging. No such interactions were in 


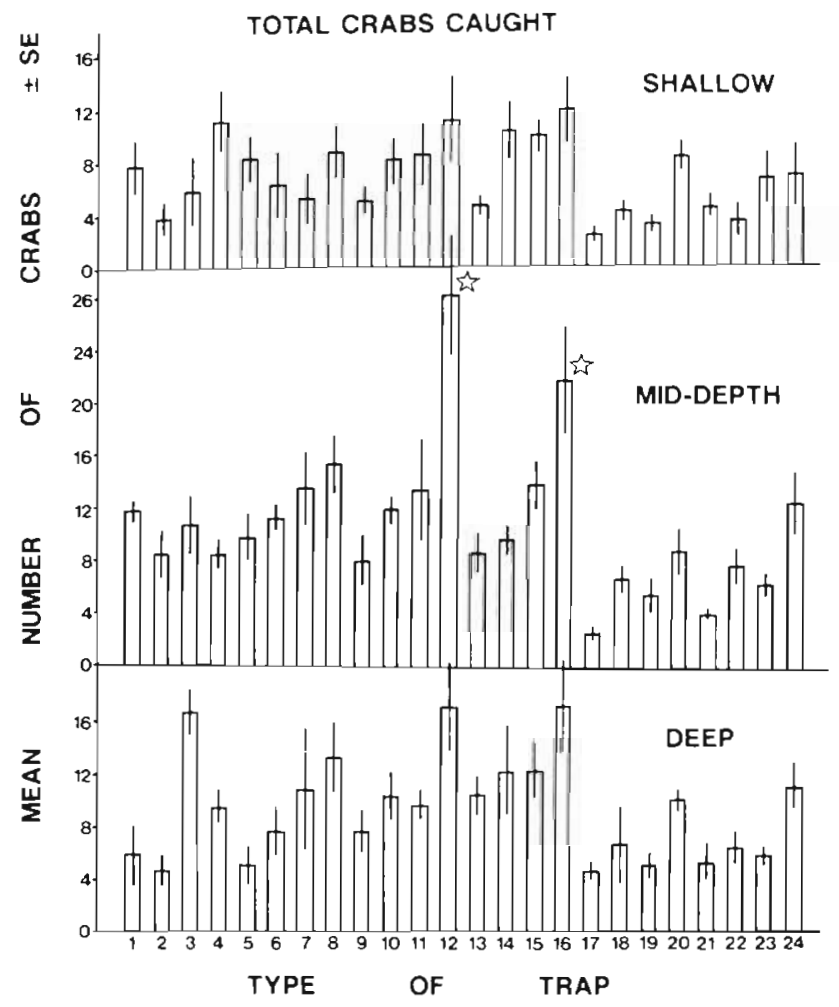

Fig. 3. Ranina ranina. Effects on CPUE of numbers due to 24 types of traps at each of 3 depths $(n=5)$. In this and subsequent figures, in indicates a significant difference among means $(p<0.05)$. See Table 1 for the identity of each trap

evidence $(p>0.05)$, allowing the treatment of this experiment as a fully orthogonal design.

\section{RESULTS}

\section{Expt 1}

Overall, more crabs were caught in the middle depth than in shallow or deep water (Fig. 3 ; cf. Table 1 for identities of traps). There was a significant interaction between depth, mesh, ply and method of hanging nets, and no significant effects due to the shape of traps (i.e. the presence of a border around traps) ( $p<0.05$, Table 2). Ryan's test revealed that Traps 12 and 16 caught more crabs than any other trap. These traps were the square and X-shaped traps (respectively), doubly-hung with $85 \mathrm{~mm}$, 4-ply net.

The percentage of the total catch that would have been retained for sale (marketable crabs) showed fewer significant effects due to trap design than the total catch (Fig. 4). The analysis of variance revealed significant interactions between depth, mesh and ply, and between depth, shape and ply (Table 2), but these differences could not be identified using Ryan's tests. The only
Table 1 Legend for Figs. 3, 4, 5 and 6. Identity of the 24 different traps used in Expt 1

\begin{tabular}{|c|c|c|c|c|}
\hline \multirow{2}{*}{$\begin{array}{l}\text { Number } \\
\text { on } x \text {-axis }\end{array}$} & \multicolumn{4}{|c|}{ Type of trap } \\
\hline & Hanging & Ply & Shape & Mesh \\
\hline 1 & single & thick & square & $25 \mathrm{~mm}$ \\
\hline 2 & double & & & \\
\hline 3 & single & thin & & \\
\hline 4 & double & & & \\
\hline 5 & single & thick & X-shaped & \\
\hline 6 & double & & & \\
\hline 7 & single & thin & & \\
\hline 8 & double & & & \\
\hline 9 & single & thick & square & $85 \mathrm{~mm}$ \\
\hline 10 & double & & & \\
\hline 11 & single & thin & & \\
\hline 12 & double & & & \\
\hline 13 & single & thick & X-shaped & \\
\hline 14 & double & & & \\
\hline 15 & single & thin & & \\
\hline 16 & double & & & \\
\hline 17 & single & thick & square & $150 \mathrm{~mm}$ \\
\hline 18 & double & & & \\
\hline 19 & single & thin & & \\
\hline 20 & double & & & \\
\hline 21 & single & thick & X-shaped & \\
\hline 22 & double & & & \\
\hline 23 & single & thin & & \\
\hline 24 & double & & & \\
\hline
\end{tabular}

significant effect was found in shallow water (where there were fewer crabs overall) where the $150 \mathrm{~mm}$ nets caught proportionately more retainable crabs.

The percentage of the catch that were male and 100-109 mm (medium-sized) showed significant interactions between mesh and ply and between mesh and hanging in the analysis of variance $(p<0.05$, Table 2). Ryan's tests on these means showed that there were proportionately less of this size-class caught in deep water than in shallow water, and that the $150 \mathrm{~mm}$ net caught fewer of these deep water crabs than the other mesh sizes (Fig. 5).

The percentage of the total catch that were females less than $69 \mathrm{~mm}$, females $70-79 \mathrm{~mm}$, females $80-89 \mathrm{~mm}$ and males 110-119 $\mathrm{mm}$ showed several significant interactions in the respective analyses of variance (Table 2) but differences among means could not be identified using Ryan's test.

The time taken to clear crabs from traps was different for different traps (significant interaction in the analysis of variance, $p<0.05$, Table 3), with significantly more time required to clear crabs from the $150 \mathrm{~mm}$ mesh traps (Fig. 6a). The damage to crabs during the clearing of traps also differed for different kinds of traps (analysis of variance, $p<0.05$ ). Significantly tewer dactyli were damaged in Traps 17 to 24 (the traps with $150 \mathrm{~mm}$ nets) than in other traps (Fig. 6b). This result was reversed for damage done to whole limbs, however, 
Table 2. Ranina ranina. Summaries of 5-factor analyses of variance to determine effects of different traps on CPUE of spanner crabs. In this and subsequent tables, ns: non-significant $(p>0.05),{ }^{\prime \prime}$ significant $(p<0.01)$, significant $(p<0.05)$

\begin{tabular}{|c|c|c|c|c|c|c|c|c|}
\hline Treatment & $\mathrm{df}$ & $\begin{array}{l}\text { Total } \\
\text { no. of } \\
\text { crabs }\end{array}$ & $\begin{array}{l}\% \text { of } \\
\text { retained } \\
\text { crabs }\end{array}$ & $\begin{array}{c}\% \text { of } \\
\text { females } \\
80-89 \mathrm{~mm}\end{array}$ & $\begin{array}{c}\% \text { of } \\
\text { females } \\
70-79 \mathrm{~mm}\end{array}$ & $\begin{array}{c}D / \mathrm{of} \\
\text { females } \\
<69 \mathrm{~mm}\end{array}$ & $\begin{array}{c}\% \text { of } \\
\text { males } \\
110-119 \mathrm{~mm}\end{array}$ & $\begin{array}{c}\% \text { of } \\
\text { males } \\
100-109 \mathrm{~mm}\end{array}$ \\
\hline Depth & 2 & $\cdots$ & $\cdots$ & $\cdots$ & $\cdots$ & $\cdots$ & ns & $\cdots$ \\
\hline Mesh & 2 & $\cdots$ & $\cdots$ & $\cdot$ & ns & ns & $\cdot$ & $\cdots$ \\
\hline Shape & 1 & ns & $\cdot$ & ns & ns & ns & ns & $\cdot$ \\
\hline Ply & 1 & $\cdots$ & ns & $\cdots$ & ns & $\cdot$ & ns & ns \\
\hline Hanging & 1 & $\cdots$ & ns & ns & ns & ns & $\cdot$ & ns \\
\hline $\mathrm{D} \times \mathrm{M}$ & 4 & ns & $\cdots$ & ns & $\cdots$ & ns & $\cdots$ & ns \\
\hline$D \times S$ & 2 & ns & ns & $\cdots$ & ns & ns & ns & $\cdot$ \\
\hline $\mathrm{D} \times \mathrm{P}$ & 2 & ns & ns & $\because$ & $\cdot$ & $\mathrm{ns}$ & ns & ns \\
\hline $\mathrm{D} \times \mathrm{H}$ & 2 & $\mathrm{~ns}$ & ns & ns & ns & ns & ns & ns \\
\hline$M \times S$ & 2 & ns & ns & ns & ns & ns & ns & ns \\
\hline$M \times P$ & 2 & ns & ns & ns & ns & ns & ns & $\cdots$ \\
\hline $\mathrm{M} \times \mathrm{H}$ & 2 & $\cdots$ & ns & ns & $\cdots$ & ns & ns & $\cdots$ \\
\hline $\mathrm{S} \times \mathrm{P}$ & 1 & ns & ns & ns & ns & ns & ns & ns \\
\hline $\mathrm{S} \times \mathrm{H}$ & 1 & ns & ns & ns & ns & ns & ns & ns \\
\hline $\mathrm{P} \times \mathrm{H}$ & 1 & $\cdots$ & ns & ns & ns & ns & ns & nos \\
\hline $\mathrm{D} \times \mathrm{S} \times \mathrm{H}$ & 2 & ns & ns & ns & ns & ns & ns & ns \\
\hline$D \times M \times S$ & 4 & ns & ns & ns & ns & ns & ns & ns \\
\hline $\mathrm{D} \times \mathrm{M} \times \mathrm{P}$ & 4 & $\cdots$ & ns & $\cdot$ & ns & ns & ns & ns \\
\hline $\mathrm{D} \times \mathrm{P} \times \mathrm{H}$ & 2 & ns & ns & ns & ns & ns & ns & ns \\
\hline $\mathrm{D} \times \mathrm{M} \times \mathrm{H}$ & 4 & ns & ns & ns & ns & ns & ns & ns \\
\hline $\mathrm{D} \times \mathrm{S} \times \mathrm{P}$ & 2 & ns & ns & $\cdots$ & $\cdot$ & ns & ns & ns \\
\hline $\mathrm{M} \times \mathrm{S} \times \mathrm{P}$ & 2 & ns & ns & ns & ns & ns & ns & ns \\
\hline $\mathrm{M} \times \mathrm{S} \times \mathrm{H}$ & 2 & ns & ns & ns & ns & ns & ns & ns \\
\hline $\mathrm{M} \times \mathrm{P} \times \mathrm{H}$ & 2 & ns & ns & ns & ns & ns & ns & ns \\
\hline $\mathrm{S} \times \mathrm{P} \times \mathrm{H}$ & 1 & ns & ns & ns & ns & ns & ns & ns \\
\hline $\mathrm{D} \times \mathrm{M} \times \mathrm{S} \times \mathrm{P}$ & 4 & ns & ns & ns & ns & $\cdot$ & ns & ns \\
\hline $\mathrm{D} \times \mathrm{M} \times \mathrm{S} \times \mathrm{H}$ & 4 & ns & ns & ns & ns & ns & ns & ns \\
\hline $\mathrm{D} \times \mathrm{M} \times \mathrm{P} \times \mathrm{H}$ & 4 & $\cdots$ & ns & ns & ns & ns & ns & $\mathrm{ns}$ \\
\hline $\mathrm{D} \times \mathrm{S} \times \mathrm{P} \times \mathrm{H}$ & 2 & ns & ns & ns & ns & ns & ns & ns \\
\hline $\mathrm{M} \times \mathrm{S} \times \mathrm{P} \times \mathrm{H}$ & 2 & ns & ns & ns & ns & ns & ns & ns \\
\hline $\mathrm{D} \times \mathrm{M} \times \mathrm{S} \times \mathrm{P} \times \mathrm{H}$ & 4 & ns & ns & ns & $\cdot$ & ns & ns & ns \\
\hline Residual & 281 & & & & & & & \\
\hline
\end{tabular}

where Traps 19 and 21 resulted in greater losses of limbs (Fig. 6c).

\section{Expt 2}

Whilst several sets of data showed significant interactions in the analyses of variance of this experiment (Table 4), only 2 sets of data showed any significant differences among means using Ryan's tests. In no analysis were there consistent influences due to bait.

Many more crabs were caught at Place 2 than at Place 1 (Fig. 7a). Ryan's test revealed no differences among means of different baits or between sets of traps and individual traps. The percentage of the total catch that were retainable for sale showed a significant effect at Place 1 where there were few crabs (Fig. 7b). Here traps set individually caught proportionately fewer retainable crabs than traps in sets.

\section{DISCUSSION}

The experiments described in this paper identified the optimal tool for estimating relative abundances of Ranina ranina using a baited trapping technique. This was a flat-framed trap with doubly-hung, 4-ply netting with a mesh-size of $85 \mathrm{~mm}$. This design caught significantly more crabs per trap-lift than any other kind of trap. The 4-ply net hung doubly probably entangles limbs of $R$. ranina better than thicker nets and better than nets hung singly. A mesh size smaller than $85 \mathrm{~mm}$ may permit some crabs to walk over the net undeterred, and a larger mesh-size may allow some crabs to avoid entanglement. The presence or absence of a border around traps did not significantly affect CPUE.

The fact that there were few effects on the different size-classes of male and female crabs due to different trapsindicates that various traps tended to fish equally as 


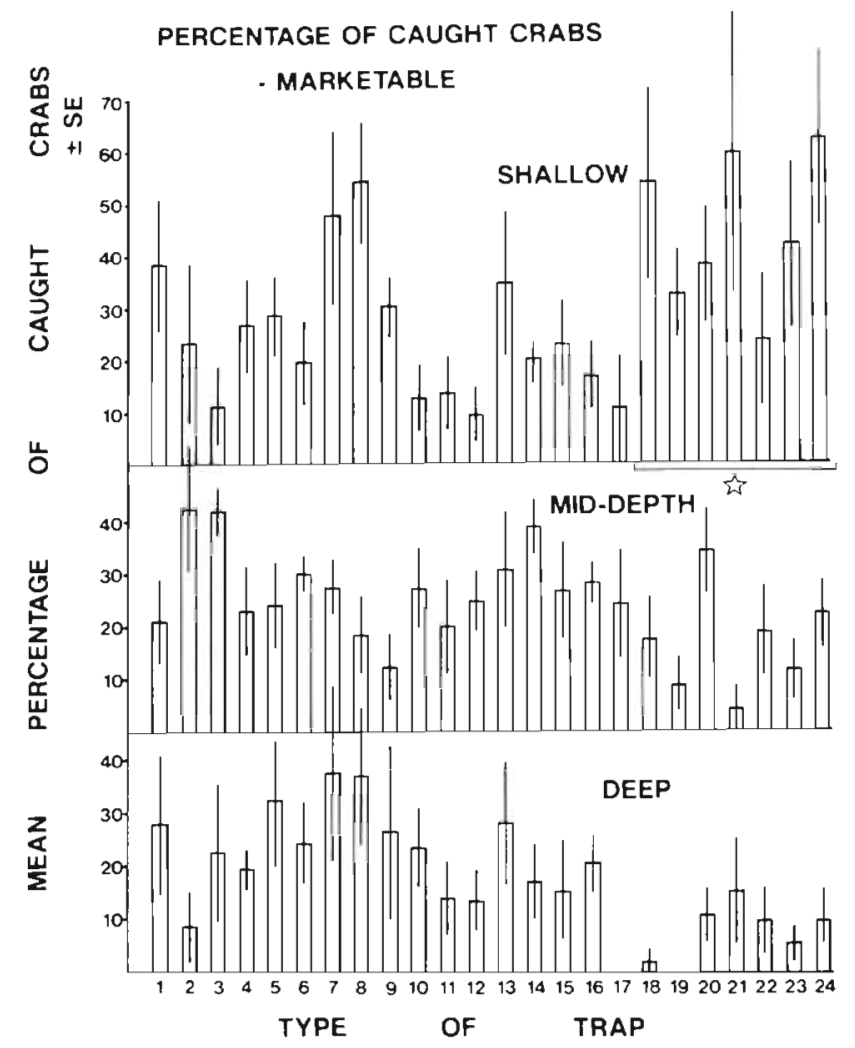

Fig. 4. Ranina ranina. Effects on CPUE of the percentage of retainable crabs due to 24 types of traps at each of 3 depths $(n=5)$. See Table 1 for the identity of each trap

PERCENTAGE OF CAUGHT CRABS

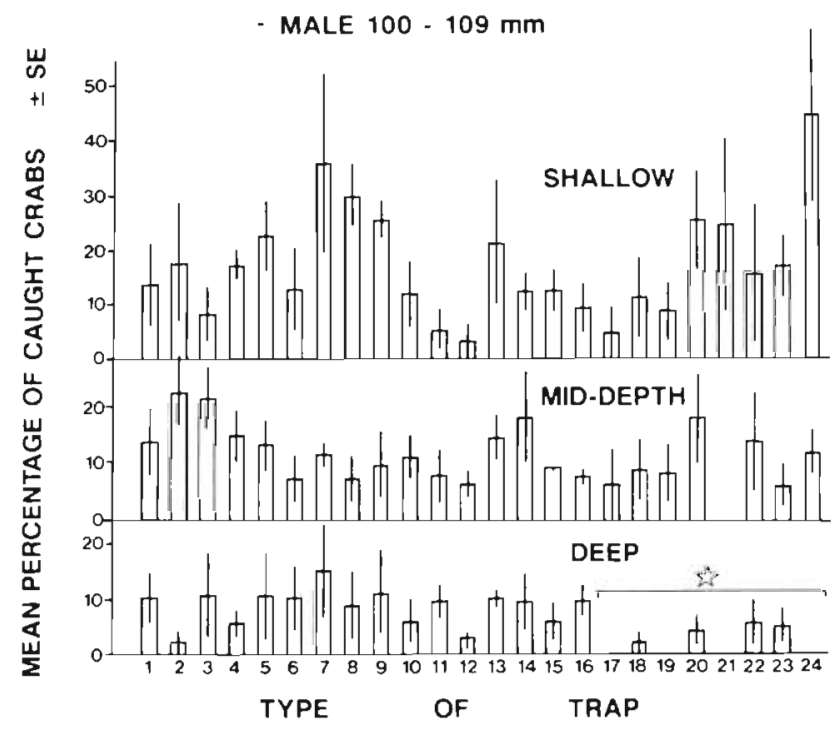

Fig. 5. Ranina ranina. Effects on CPUE of the percentage of male crabs $100-109 \mathrm{~mm}$ due to 24 types of traps at each of 3 depths $(n=5)$. See Table 1 for the identity of each trap
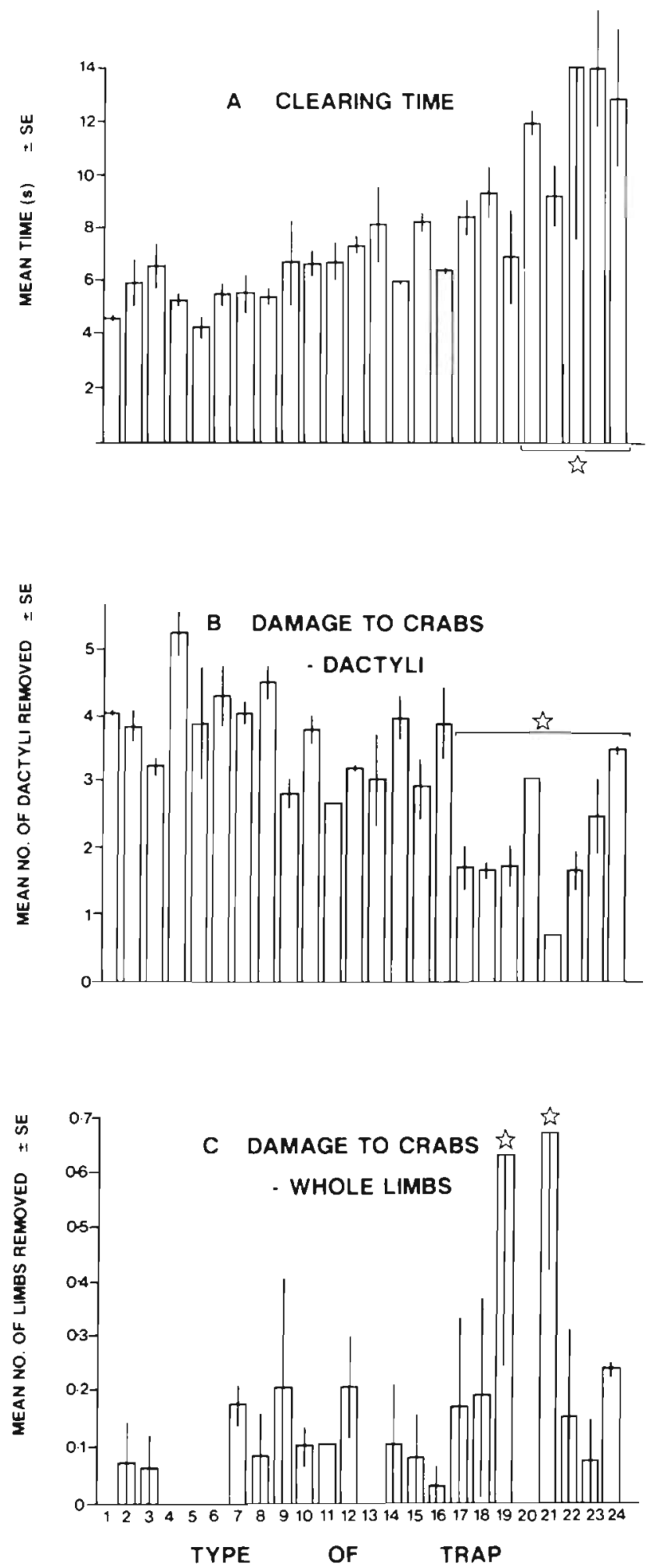

Fig. 6. Ranina ranina. (A) Time taken to remove crabs from 24 types of traps $(n=2)$. (B) Number of dactyli removed from crabs due to removal from 24 types of traps $(n=2)$. (C) Number of whole limbs removed from crabs due to removal from 24 types of traps $(n=2)$. See Table 1 for the identity of each trap 
Table 3. Ranina ranina. Summaries of 4 -factor analyses of variance to determine effects of different traps on the time required to clear crabs from traps and the damage done to crabs during clearing

\begin{tabular}{|c|c|c|c|c|}
\hline Treatment & $d f$ & $\begin{array}{l}\text { Time for } \\
\text { clearing }\end{array}$ & $\begin{array}{l}\text { Removal } \\
\text { of dactyli }\end{array}$ & $\begin{array}{l}\text { Removal } \\
\text { of limbs }\end{array}$ \\
\hline Mesh & 2 & $\cdots$ & $\cdots$ & $\cdots$ \\
\hline Shape & 1 & $\cdot$ & ns & ns \\
\hline Ply & 1 & ns & $\cdots$ & as \\
\hline Hanging & 1 & ns & $\cdots$ & $\cdot$ \\
\hline$M \times S$ & 2 & $\cdots$ & ns & ns \\
\hline$M \times P$ & 2 & ns & $\because$ & ns \\
\hline $\mathrm{M} \times \mathrm{H}$ & 2 & $\cdots$ & ns & ns \\
\hline $\mathrm{S} \times \mathrm{P}$ & 1 & ns & ns & ns \\
\hline $\mathrm{S} \times \mathrm{H}$ & 1 & ns & ns & ns \\
\hline $\mathrm{P} \times \mathrm{H}$ & 1 & ns & ns & ns \\
\hline $\mathrm{M} \times \mathrm{S} \times \mathrm{P}$ & 2 & ns & ns & $\cdot$ \\
\hline $\mathrm{M} \times \mathrm{S} \times \mathrm{H}$ & 2 & ns & ns & ns \\
\hline $\mathrm{M} \times \mathrm{P} \times \mathrm{H}$ & 2 & ns & ns & ns \\
\hline $\mathrm{S} \times \mathrm{P} \times \mathrm{H}$ & 1 & ns & $\mathrm{nS}$ & ns \\
\hline $\mathrm{M} \times \mathrm{S} \times \mathrm{P} \times \mathrm{H}$ & 2 & " & ns & $\cdots$ \\
\hline Residual & 24 & & & \\
\hline
\end{tabular}

effectively for these various sizes of both sexes. The only exception was for the CPUE of crabs of commercial value (Fig. 4). This size-class was caught better on a larger mesh-size only when there were very few crabs available for capture, whilst medium-sized male crabs were caught better with smaller mesh-sizes when there were few crabs available. This indicates significant variation between treatments for these size-classes and no consistent trend. The trap currently used by commercial fishermen in New South Wales (developed through trial and error over 6 to 12 mo of fishing) is that trap we found to be most successful, although 9- to 12-ply net tends to be used instead of 4 -ply - heavier nets require less maintenance and replacement than lighter nets.
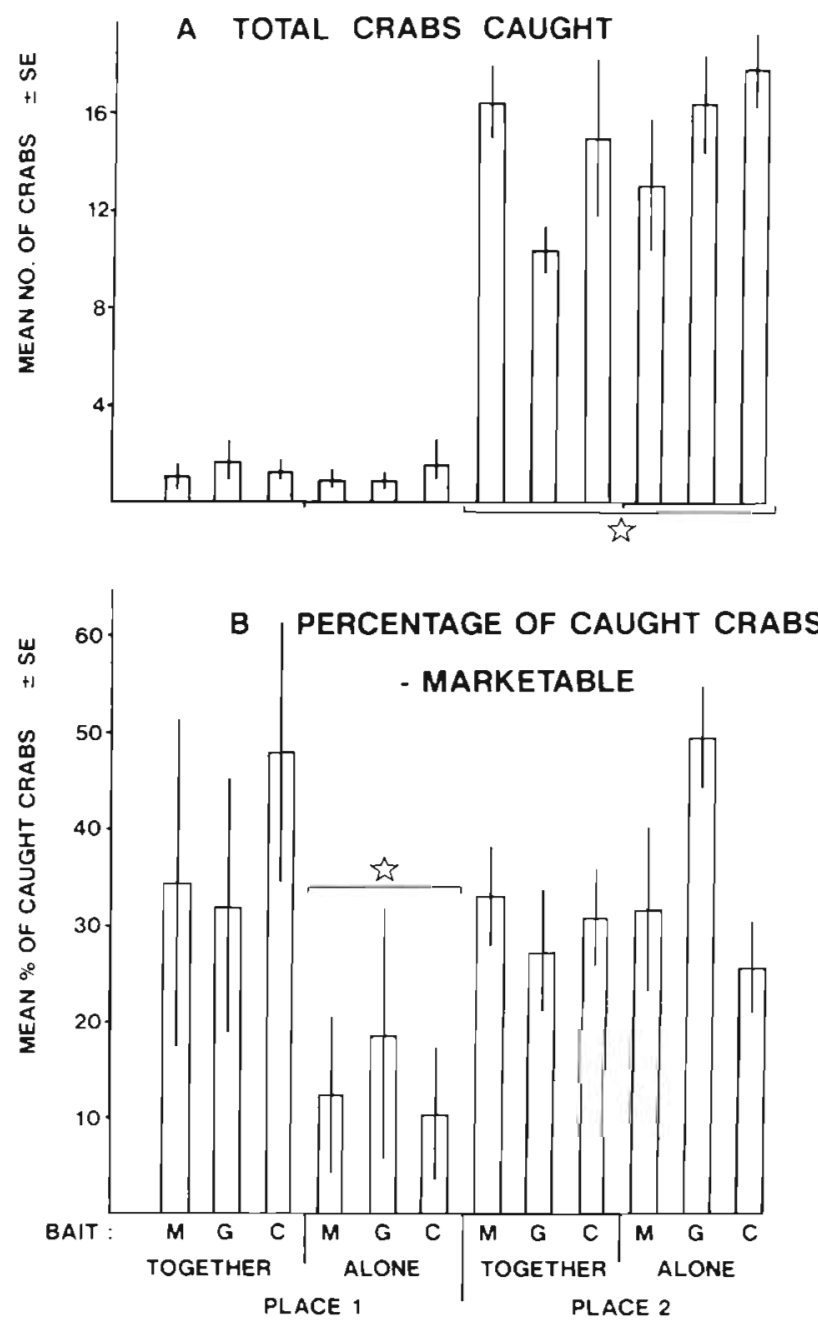

Fig. 7 Ranina ranina. Effects on CPUE of (A.) total number of crabs and (B) percentage of retainable crabs caught on traps set in different places, $60 \mathrm{~m}$ apart and individually, and using 3 different types of bait $(\mathrm{M}=$ Mugil cephalus, $\mathrm{G}=$ Girella tricuspidata, $\mathrm{C}=$ Cheilodactylus douglassin $)(n=12)$

Table 4. Ranina ranina. Summaries of 4-factor analyses of variance to determine effects on CPUE due to competition between traps set $60 \mathrm{~m}$ apart, different kinds of bait and in different places

\begin{tabular}{|c|c|c|c|c|c|c|c|c|}
\hline Treatment & $\mathrm{df}$ & $\begin{array}{l}\text { Total } \\
\text { no. of } \\
\text { crabs }\end{array}$ & $\begin{array}{l}\% \text { of } \\
\text { retained } \\
\text { crabs }\end{array}$ & $\begin{array}{c}\% \text { of } \\
\text { females } \\
80-89 \mathrm{~mm}\end{array}$ & $\begin{array}{c}\% \text { of } \\
\text { females } \\
70-79 \mathrm{~mm}\end{array}$ & $\begin{array}{c}\% \text { of } \\
\text { males } \\
110-119 \mathrm{~mm}\end{array}$ & $\begin{array}{c}\% \text { of } \\
\text { males } \\
100-109 \mathrm{~mm}\end{array}$ & $\begin{array}{c}\% \text { of } \\
\text { males } \\
90-99 \mathrm{~mm}\end{array}$ \\
\hline Place & 1 & $\cdots$ & ns & $\cdots$ & ns & ns & ns & ns \\
\hline Competition & 1 & ns & ns & ns & ns & ns & ns & ns \\
\hline Bait & 2 & ns & $\mathrm{ns}$ & ns & ns & ns & $\mathrm{ns}$ & ns \\
\hline Sets & 12 & ns & ns & ns & $\cdot$ & $\cdots$ & ns & $\cdot$ \\
\hline$P \times C$ & 1 & ns & $\cdots$ & ns & ns & ns & $\cdots$ & ns \\
\hline$P \times B$ & 2 & ns & ns & ns & ns & ns & ns & ns \\
\hline $\mathrm{C} \times \mathrm{B}$ & 2 & ns & ns & ns & ns & ns & $\mathrm{ns}$ & ns \\
\hline $\mathrm{P} \times \mathrm{C} \times \mathrm{B}$ & 2 & · & ns & ns & ns & ns & ns & ns \\
\hline$B \times S$ & 24 & ns & ns & • & $\cdot$ & $\cdots$ & ns & ns \\
\hline Residual & 46 & & & & & & & \\
\hline
\end{tabular}


A greater number of dactyli were generally removed from crabs caught on $25 \mathrm{~mm}$ and $85 \mathrm{~mm}$ meshes, but these mesh-sizes led to less removal of whole limbs. In the only study of the effects of limb-damage on the survivorship of Ranina ranina, Onizuka (1972) found that $90 \%$ of crabs survived with dactyli removed from 4 limbs, whilst only $30 \%$ of crabs survived with 1 whole limb removed. These results suggest that smaller mesh-sizes will minimize mortality due to removal from traps. It also took significantly longer to remove crabs from the larger mesh-size than smaller meshes, indicating that smaller mesh-sizes are optimal with respect to clearing-time.

Since no bait caught more crabs than any other, future sampling will use whatever bait is available. We are also now confident that traps set $60 \mathrm{~m}$ apart fish as effectively as individual traps set much further apart. Thus, traps set $60 \mathrm{~m}$ apart do not compete with one another for the same crabs and so can be considered as true independent replicates. Indeed, the only effect of using a $60 \mathrm{~m}$ distance between traps on a set compared to setting traps individually was to enhance the capture of large, male crabs when the relative number of crabs appeared low.

Thomas (1953), Sinoda \& Kobayasi (1969) and Miller (1983) point out the need for examinations of the reliability of methods which estimate the relative abundances of organisms using baited traps. In this study, a methodology involving manipulative fjeld experiments was shown to achieve this by testing discrete hypotheses concerning the various methods available to catch and sample Ranina ranina.

Acknowledgements. This study was funded by a Fishing Industry Research Trust grant. We sincerely thank J. Lavis for the use of his vessel, his expertise and for many helpful discussions concerning the capture of spanner crabs. We acknowledge Drs A. Underwood, W. Fletcher, J. Bell, R. Kearney and $\mathrm{Mr} \mathrm{C}$. Gray for critically reading the manuscript. We also thank G. Gordon for assistance with computing, and J. Matthews and $\mathrm{O}$. Craig for assistance with constructing fishing gear

\section{LITERATURE CITED}

Barnard, K. H. (1950). Descriptive catalogue of South African decapod crustacea. Ann. S. Atr. Mus. 38: 396-399

Brown, I. W. (1986). Population biology of the spanner crab in south-east Queensland. Fishing industry project 81/71 final report

Collie, J. S., Sissenwine, M. P. (1983). Estimating population size from relative abundance data measured with error. Can. J. Fish. Aquat. Sci. 40: 1871-1879

Fielding, A., Haley, S. R. (1976). Sex ratio size at reproductive maturity and reproduction of the Hawaiian kona crab
Ranina ranina (Linnaeus) (Brachyura, Gymnopleura, Raninidae). Pacif. Sci. 30: 131-145

Fogarty, M. J., Borden, D. V. D. (1980). Effects of trap venting on gear selectivity in the inshore Rhode Is. American lobster Homarus amenicanus fishery. Fish. Bull. U.S. 77 : 925-933

Hamley, J. M. (1975). Review of gillnet selectivity. J. Fish. Res. Bd Can. 32: 1943-1969

Jester, D. B. (1973). Variations in catchability of fishes with color of gillnets. Trans. Am. Fish. Soc. 102: 109-115

Jester, D. B. (1977). Effects of color, mesh-size, fishing in seasonal concentrations, and baiting on catch rates of fishes in gillnets. Trans. Am. Fish. Soc. 106: 43-56

Kjelson, M. A., Colby, D. R. (1977). The evaluation and use of gear efficiencies in the estimation of estuarine fish abundance. In: Wiley, M. (ed.) Estuarine processes, Vol 2. Academic Press, New York, p. 416-424

Larkins, H. A. (1963). Comparison of salmon catches in monofilament and multifilament gillnets. Comml Fish. Rev, 25: $1-11$

Larkins, H. A. (1964). Comparison of salmon catches in monofilament and multifilament gillnets - Part II. Comml Fish. Rev. 26: $1-7$

Miller. R. J. (1978). Entry of Cancer productus to baited traps. J. Cons. int. Explor. Mer 38: 220-225

Miller, R. J. (1979). Saturation of crab traps: reduced entry and escapement. J. cons. int. Explor. Mer 38: 338-345

Miller, R. J. (1981). Design criteria for crab traps. J. Cons int. Explor. Mer 39: 140-147

Miller, R. J. (1983). Considerations for conducting field experiments with baited traps. Fisheries 8: 14-17

Onizuka, E. W (1972). Management and development investigations of the kona crab, Ranina ranina (Linnaeus). Div. Fish and Game, Dept Land and Nat. Res. Report, Honolulu, Hawaii

Ryan, T A. (1959). Multiple comparisons in psychological research. Psychol. Bull. 56: 26-47

Scheffé, H. (1959). The analysis of variance. Wiley, New York Sinoda, M., Kobayasi. T (1969). Studies on the fishery of Zuwai crab in the Japan Sea - VI. Efficiency of the Toyama Kago (a kind of crab trap) in capturing the Beni-zuwai crab. Bull. Jap. Soc. scient. Fish. 35: 948-956

Sissenwine, M. P. (1984). The uncertain environment of fishery scientists and managers. Mar Res. Econ. 1: 1-30

Sissenwine, M. P., Kirkley, J. E. (1982). Practical aspects and limitations of fishery management techniques. Mar. Policy 6: $43-58$

Sissenwine, M. P., Azarovitz, T., Suomala, J. B. (1983). Determination of fish abundance. In: Macdonald, A. G., Priede, I. G. (eds.) Experimental biology at sea. Academic Press, New York, p. 51-101

Skinner, D. G., Hill, B. J. (1986). Catch rate and emergence of male and female spanner crabs (Ranina ranna) in Australia. Mar Biol. 91· 461-465

Skinner, D. G., Hill, B. J. (1987). Feeding and reproductive behaviour and their effect on catchability of the spanner crab Ranina ranina. Mar. Biol. 93: 211-218

Tahil. A. S. (1983). Reproductive period and exploitation of the red frog crab, Ranina ranina (Linnaeus 1758) in Central Tawi-Tawi, Philippines. Philipp. Scient. 20:57-72

Thomas, H. J. (1953). The efficiency of fishing methods employed in the capture of lobsters and crabs. J. Cons. int. Explor. Mer 18: 333-350 